\title{
Communication \\ Serological Evidence of Natural Exposure to Tick-Borne Pathogens in Horses, Romania
}

\author{
Andreea Monica Bogdan, Mariana Ionita * and Ioan Liviu Mitrea (D) \\ Department of Parasitology and Parasitic Diseases \& Animal Biology, Faculty of Veterinary Medicine, \\ University of Agronomic Sciences and Veterinary Medicine of Bucharest, 11464 Bucharest, Romania; \\ andreeabogdan01@yahoo.com (A.M.B.); liviumitrea@yahoo.com (I.L.M.) \\ * Correspondence: ionitamary@yahoo.com
}

Citation: Bogdan, A.M.; Ionita, M.; Mitrea, I.L. Serological Evidence of Natural Exposure to Tick-Borne Pathogens in Horses, Romania. Microorganisms 2021, 9, 373. https://doi.org/10.3390/ microorganisms 9020373

Academic Editor: Gerold Stanek Received: 22 December 2020 Accepted: 9 February 2021 Published: 12 February 2021

Publisher's Note: MDPI stays neutral with regard to jurisdictional claims in published maps and institutional affiliations.

Copyright: (C) 2021 by the authors. Licensee MDPI, Basel, Switzerland. This article is an open access article distributed under the terms and conditions of the Creative Commons Attribution (CC BY) license (https:/ / creativecommons.org/licenses/by/ $4.0 /)$.

\begin{abstract}
The purpose of this study was to investigate the seroprevalence of selected tick-bornepathogens (TBPs) among Romanian horses. For this, a total of 223 animals originating from north, central, and southeast Romania, including horses from stud farms $(n=118)$ and working horses $(n=105)$, were tested using a commercial rapid ELISA-based test. Overall, $10.3 \%$ (95\% confidence interval (CI): $6.7-15.1 \%$ ) of the tested horses were seropositive for antibodies (Ab) against Anaplasma phagocytophilum. Additionally, 18.8\% (95\% CI: 13.9-24.6\%) and 0.5\% (95\% CI: $0.01-2.5 \%$ ) of horses were seropositive for $\mathrm{Ab}$ against Borrelia burgdorferi sensu lato and Ehrlichia spp., respectively. Among the tested horses, $3.1 \%$ were seroreactive to two or three pathogens. These findings show the natural exposure of Romanian horses to zoonotic tick-borne pathogens and emphasize the need for further studies to better understand the epidemiology of equine tick-borne diseases in Romania.
\end{abstract}

Keywords: tick-borne pathogens; horses; Romania; serological test

\section{Introduction}

Ticks are recognized among the main vectors of diseases in humans and animals, due to their wide distribution and the wide variety of pathogens they transmit, including pathogens with zoonotic potential. In recent years, their importance has increased all over the world, since the (re)-emergence and spread of tick-borne diseases (TBD) have become a threat to public and animal health [1,2]. Among the tick-borne pathogens (TBPs), Anaplasma phagocytophilum, Lyme disease-associated Borrelia spp., and several Rickettsia spp. are the most common pathogens reported to infect humans and animals, including horses $[3,4]$.

The zoonotic tick-borne pathogens A. phagocytophilum and B. burgdorferi s.l. are on the rise [3,5], but little is known about their distribution in horses.

A. phagocytophilum (order: Rickettsiales, family: Anaplasmataceae) is a widespread, multihost, obligate intracellular Gram-negative bacterium that is able to infect the granulocytes, mainly neutrophils, of several wild and domestic animal species, including horses. It is the causative agent of tick-borne fever of ruminants (TBF) and of human, canine, feline, and equine granulocytic anaplasmosis (HGA, CGA, FGA, and EGA, respectively) [3,6]. $A$. phagocytophilum is also regarded as an emerging zoonotic pathogen which is becoming increasingly recognized in the Northern Hemisphere [2,7].

Horses infected by $A$. phagocytophilum develop a disease known as equine granulocytic anaplasmosis (EGA) (formerly equine granulocytic ehrlichiosis), characterized by fever, depression, anorexia, ataxia and reluctance to move, limb edemas, icterus, and petechiae; laboratory pathology may include anemia, leukopenia, and thrombocytopenia [8-10]. Additionally, neurological signs have recently been reported [11].

For all species, A. phagocytophilum is transmitted through the bite of an infected tick. In Europe, Ixodes ricinus is the main vector, while a variety of wild mammals, such as wild ruminants, rodents, and insectivores may represent efficient reservoir hosts, contributing 
to endemic cycles [3]. Transstadial transmission is considered important in maintaining of A. phagocytophilum within enzootic cycles, as transovarial transmission has not described for this tick. Recently, four different $A$. phagocytophilum ecotypes (genetic variants) were identified which could circulate within different enzootic cycles in relation to species of vertebrate host and tick vector. Of these, ecotype I has the highest zoonotic potential and the broadest host range, including horses [12].

B. burgdorferi s.l. is the causative agent of Lyme disease, an important tick-borne disease in humans and various animals, including horses [13]. Most B. burgdorferi s.l.-infected horses are asymptomatic, but there are some documented naturally occurring syndromes associated with B. burgdorferi infection which include neuroborreliosis, cutaneous pseudolymphoma, and uveitis [14].

Studies on the presence and distribution of tick-borne pathogens in Romanian horses are very scarce. Several previous studies in Romania indicated the circulation of some TBPs at the tick-host interface, demonstrated by molecular investigations. In particular, DNA of A. phagocytophilum has been detected in I. ricinus, both feeding ticks collected from cattle and horses [15] and questing ticks [16], and tissue samples collected from red foxes and rodents [17,18], while B. burgdorferi s.l. DNA has been detected in questing ticks [19] and feeding ticks collected from horses [15]. However, there is very scant information about the spread of these pathogens among horses reared in Romania. Therefore, the aim of the study was to investigate the infection status of $A$. phagocytophilum and other selected zoonotic tick-borne pathogens in equine populations from different geographical regions of Romania and to evaluate a possible role of horses in the epidemiology of zoonotic tick-borne diseases.

\section{Materials and Methods}

\subsection{Study Areas, Animals, and Investigations}

Between June 2017 and October 2019, a total of 223 horses originating from five counties (administrative units) in north, central, and southeast Romania were included in the study (Figure 1).

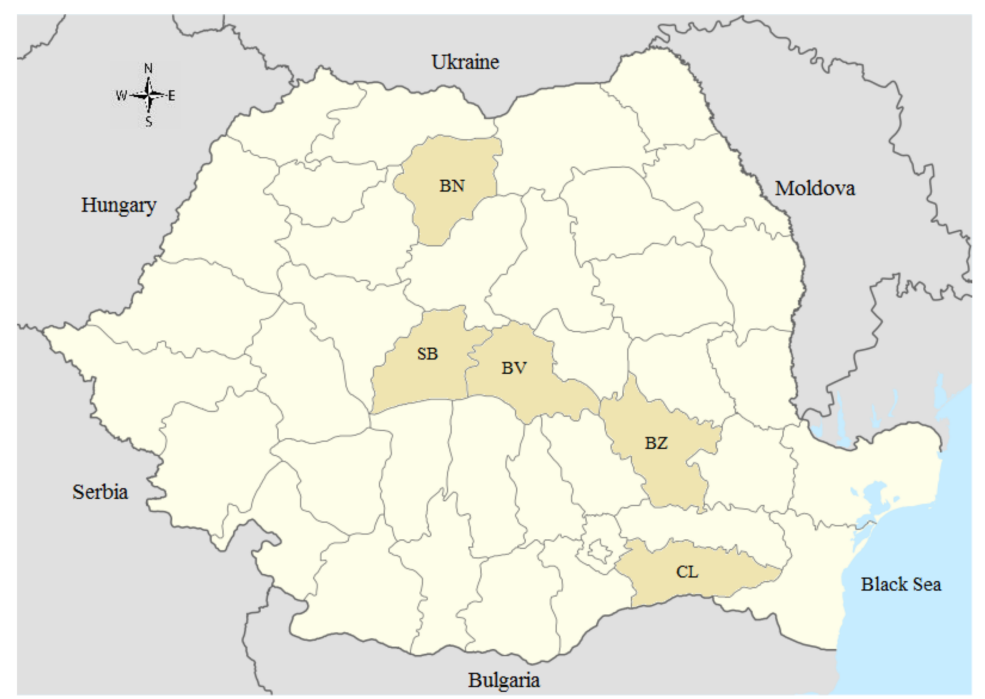

Figure 1. Map of Romania showing counties where horse sampling was carried-out. BN-Bistrita Nasaud; SB-Sibiu; BV—Brasov; BZ—Buzau; CL—Calarasi.

Horses were actively racing and reared in stud farms and in small individual farms (working horses) located in hilly and lowland areas of Romania.

Details related to age, gender, health status, breed, use, and origin were registered for each animal. 
According to their activities, animals were categorized into two groups on the basis of raising system: stud farms and working horses.

Horse blood samples were collected from the jugular vein in ethylenediaminetetraacetic acid (EDTA)-sterile blood collection tubes.

All samples were tested for the presence of circulating antibodies ( $\mathrm{Ab})$ against $A$. phagocytophilum, B. burgdorferi sensu lato, and Ehrlichia spp. using a commercially available ELISA-based test (SNAP ${ }^{\circledR} 4 \mathrm{Dx}^{\circledR}$ Plus; IDEXX Laboratories, Inc.), according to the manufacturer's instructions.

The SNAP ${ }^{\circledR} 4 \mathrm{Dx}^{\circledR}$ assay was originally developed to detect $\mathrm{Ab}$ against $A$. phagocytophilum, B. burgdorferi s.l., and Ehrlichia spp. (E. canis, E. chaffeensis, and E. ewingii) in dogs but it has also shown useful results in horses [20-22]. The assay uses an all-species conjugate and it is not species-specific for animals; moreover, it has been validated for horses, with $100 \%$ sensitivity and specificity for the detection of antibodies against $A$. phagocytophilum and 100\% and 95\%, respectively, for B. burgdorferi s.l.; furthermore, no cross-reactions with either E. canis or the heartworm analytes in the $\mathrm{SNAP}^{\circledR} 4 \mathrm{Dx}{ }^{\circledR}$ assay were found [23].

\subsection{Statistical Analysis}

The collected data were statistically analyzed using Quantitative Parasitology 3.0 software. The prevalence and corresponding 95\% confidence intervals (95\% CI) were calculated. Differences among categories were assessed by means of Fisher's exact test and were considered statistically significant for values with $p<0.05$.

\section{Results}

To assess the infection status of $A$. phagocytophilum and other selected tick-borne pathogens, namely, B. burgdorferi s.l. and Ehrlichia spp., in horses reared in Romania, a total of 223 animals, including 118 horses from stud farms and 105 working horses, originating from three geographical regions, were serologically tested.

Details related to the geographical characterization of the horses' originating areas are presented in Table 1.

Table 1. Geographic characterization of the horses' originating areas.

\begin{tabular}{|c|c|c|c|}
\hline Region/County & Relief [Altitudes] & Climate $\left[\mathrm{T}^{*}\right]$ & Vegetations \\
\hline \multicolumn{4}{|l|}{ North } \\
\hline $\mathrm{BN}$ & $\begin{array}{l}\text { Lowlands and hills } \\
\qquad(350-800 \mathrm{~m})\end{array}$ & $\begin{array}{l}\text { Continental } \\
\left(8-9^{\circ} \mathrm{C}\right)\end{array}$ & $\begin{array}{c}\text { Meadows and } \\
\text { pastures that } \\
\text { alternate with forests }\end{array}$ \\
\hline \multicolumn{4}{|l|}{ Center } \\
\hline BV & $\begin{array}{l}\text { Sub-mountain hills } \\
\quad(500-800 \mathrm{~m})\end{array}$ & $\begin{array}{l}\text { Continental } \\
\left(8-9^{\circ} \mathrm{C}\right)\end{array}$ & $\begin{array}{c}\text { Meadows and } \\
\text { pastures that } \\
\text { alternate with forests }\end{array}$ \\
\hline SB & $\begin{array}{l}\text { Lowlands and hills } \\
\qquad(400-500 \mathrm{~m})\end{array}$ & $\begin{array}{l}\text { Continental } \\
\left(8-9^{\circ} \mathrm{C}\right)\end{array}$ & $\begin{array}{c}\text { Meadows and } \\
\text { pastures that } \\
\text { alternate with forests }\end{array}$ \\
\hline \multicolumn{4}{|l|}{ Southeast } \\
\hline $\mathrm{BZ}$ & $\begin{array}{l}\text { Lowlands and hills } \\
\qquad(80-300 \mathrm{~m})\end{array}$ & $\begin{array}{l}\text { Continental } \\
\left(10-11^{\circ} \mathrm{C}\right)\end{array}$ & $\begin{array}{c}\text { Meadows and } \\
\text { pastures that } \\
\text { alternate with forests }\end{array}$ \\
\hline CL & $\begin{array}{l}\text { Lowlands } \\
(15-75 \mathrm{~m})\end{array}$ & $\begin{array}{l}\text { Continental } \\
\left(10.5-12.5^{\circ} \mathrm{C}\right)\end{array}$ & $\begin{array}{l}\text { Pastures, clusters of } \\
\text { shrubs, and forests }\end{array}$ \\
\hline
\end{tabular}

Horses aged between 8 months and 26 years (mean 9 years; standard deviation (SD) 5.4) were of both genders and pure- and mixed-breed (Table 2). 


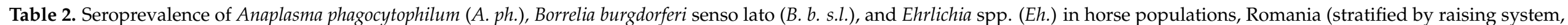
age, gender, breed, and region).

\begin{tabular}{|c|c|c|c|c|c|c|c|c|c|c|c|c|c|}
\hline \multirow[b]{2}{*}{ Group } & \multirow{2}{*}{$\begin{array}{l}\text { Total } \\
\text { Tested } \\
(n)\end{array}$} & \multicolumn{2}{|c|}{ Total Positive (\%) } & \multicolumn{2}{|c|}{ A.ph. Positive } & \multicolumn{2}{|c|}{ B.b. s.l. Positive } & \multicolumn{2}{|c|}{ Eh. Positive } & \multicolumn{2}{|c|}{ A.ph. + B.b.s.l. } & \multicolumn{2}{|c|}{ A. ph. + B. b.s.l. + Eh. } \\
\hline & & $n$ & $\begin{array}{c}\% \\
(95 \% \mathrm{CI})\end{array}$ & $n$ & $\begin{array}{c}\% \% \\
(95 \% \mathrm{CI})\end{array}$ & $n$ & $\begin{array}{c}\% \\
(95 \% \mathrm{CI})\end{array}$ & $n$ & $\begin{array}{c}\% \\
(95 \% \mathrm{CI})\end{array}$ & $n$ & $\begin{array}{c}\% \% \\
(95 \% \mathrm{CI})\end{array}$ & $n$ & $\begin{array}{c}\% \% \\
(95 \% \mathrm{CI})\end{array}$ \\
\hline Raising system & & & * & & & & * & & & & & & \\
\hline stud farm & 118 & 19 & $\begin{array}{c}16.1 \\
(10.0-24.0)\end{array}$ & 8 & $\begin{array}{c}6.8 \\
(2.9-12.9)\end{array}$ & 12 & $\begin{array}{c}10.2 \\
(5.4-17.1)\end{array}$ & 0 & $\begin{array}{c}0.0 \\
(0.0-3.1)\end{array}$ & 1 & $\begin{array}{c}0.8 \\
(0.0-4.6)\end{array}$ & 0 & $\begin{array}{c}0.0 \\
(0.0-3.1)\end{array}$ \\
\hline $\begin{array}{l}\text { working } \\
\text { horses }\end{array}$ & 105 & 41 & $\begin{array}{c}39.0 \\
(29.7-49.0)\end{array}$ & 15 & $\begin{array}{c}14.3 \\
(8.2-22.4)\end{array}$ & 30 & $\begin{array}{c}28.6 \\
(20.2-38.2)\end{array}$ & 1 & $\begin{array}{c}1.0 \\
(0.0-5.2)\end{array}$ & 5 & $\begin{array}{c}4.8 \\
(1.6- \\
10.8)\end{array}$ & 1 & $\begin{array}{c}1.0 \\
(0.0-5.2)\end{array}$ \\
\hline \multicolumn{14}{|l|}{ Age (years) } \\
\hline$<5$ & 65 & 12 & $\begin{array}{c}18.5 \\
(9.9-30.0)\end{array}$ & 5 & $\begin{array}{c}7.7 \\
(2.5-17.0)\end{array}$ & 7 & $\begin{array}{c}10.8 \\
(4.4-20.9)\end{array}$ & 0 & $\begin{array}{c}0.0 \\
(0.0-5.5)\end{array}$ & 0 & $\begin{array}{c}0.0 \\
(0.0-5.5)\end{array}$ & 0 & $\begin{array}{c}0.0 \\
(0.0-5.5)\end{array}$ \\
\hline $5-10$ & 81 & 24 & $\begin{array}{c}31.2 \\
(21.0-42.7)\end{array}$ & 8 & $\begin{array}{c}9.9 \\
(4.4-18.5)\end{array}$ & 16 & $\begin{array}{c}19.8 \\
(11.7-30.1)\end{array}$ & 0 & $\begin{array}{c}0.0 \\
(0.0-4.5)\end{array}$ & 2 & $\begin{array}{c}2.5 \\
(0.3-8.6)\end{array}$ & 0 & $\begin{array}{c}0.0 \\
(0.0-4.5)\end{array}$ \\
\hline$>10$ & 77 & 24 & $\begin{array}{c}29.6 \\
(20.0-40.8)\end{array}$ & 10 & $\begin{array}{c}13.0 \\
(6.4-22.6)\end{array}$ & 19 & $\begin{array}{c}24.7 \\
(15.5-35.8)\end{array}$ & 1 & $\begin{array}{c}1.3 \\
(0.0-7.0)\end{array}$ & 4 & $\begin{array}{c}5.2 \\
(1.4- \\
12.8)\end{array}$ & 1 & $\begin{array}{c}1.3 \\
(0.0-0.7)\end{array}$ \\
\hline Gender & & & * & & & & * & & & & & & \\
\hline male & 88 & 34 & $\begin{array}{c}38.63 \\
(28.4-49.6)\end{array}$ & 12 & $\begin{array}{c}13.6 \\
(7.2-22.6)\end{array}$ & 26 & $\begin{array}{c}29.5 \\
(21.6-38.6)\end{array}$ & 0 & $\begin{array}{c}0.0 \\
(0.0-4.1)\end{array}$ & 6 & $\begin{array}{c}6.8 \\
(2.5- \\
14.2)\end{array}$ & 0 & $\begin{array}{c}0.0 \\
(0.0-4.1)\end{array}$ \\
\hline female & 135 & 26 & $\begin{array}{c}19.25 \\
(13.0-27.0)\end{array}$ & 11 & $\begin{array}{c}8.1 \\
(4.1-14.1)\end{array}$ & 16 & $\begin{array}{c}11.9 \\
(6.9-18.5)\end{array}$ & 1 & $\begin{array}{c}0.7 \\
(0.0-4.1)\end{array}$ & 0 & $\begin{array}{c}0.0 \\
(0.0-2.7)\end{array}$ & 1 & $\begin{array}{c}0.7 \\
(0.0-4.1)\end{array}$ \\
\hline Horse breed & & & $*$ & & & & $*$ & & & & & & \\
\hline Pure-breed & 113 & 19 & $\begin{array}{c}16.8 \\
(10.4-25.0)\end{array}$ & 8 & $\begin{array}{c}7.1 \\
(3.1-13.5)\end{array}$ & 12 & $\begin{array}{c}10.6 \\
(5.6-17.8)\end{array}$ & 0 & $\begin{array}{c}0.0 \\
(0.0-3.2)\end{array}$ & 1 & $\begin{array}{c}0.9 \\
(0.0-4.8)\end{array}$ & 0 & $\begin{array}{c}0.0 \\
(0.0-3.2)\end{array}$ \\
\hline Mixed-breed & 110 & 41 & $\begin{array}{c}37.3 \\
(28.2-47.0)\end{array}$ & 15 & $\begin{array}{c}13.6 \\
(7.8-21.5)\end{array}$ & 30 & $\begin{array}{c}27.3 \\
(19.2-36.6)\end{array}$ & 1 & $\begin{array}{c}0.9 \\
(0.0-5.0)\end{array}$ & 5 & $\begin{array}{c}4.5 \\
(1.5- \\
10.3)\end{array}$ & 1 & $\begin{array}{c}0.9 \\
(0.0-5.0)\end{array}$ \\
\hline
\end{tabular}


Table 2. Cont.

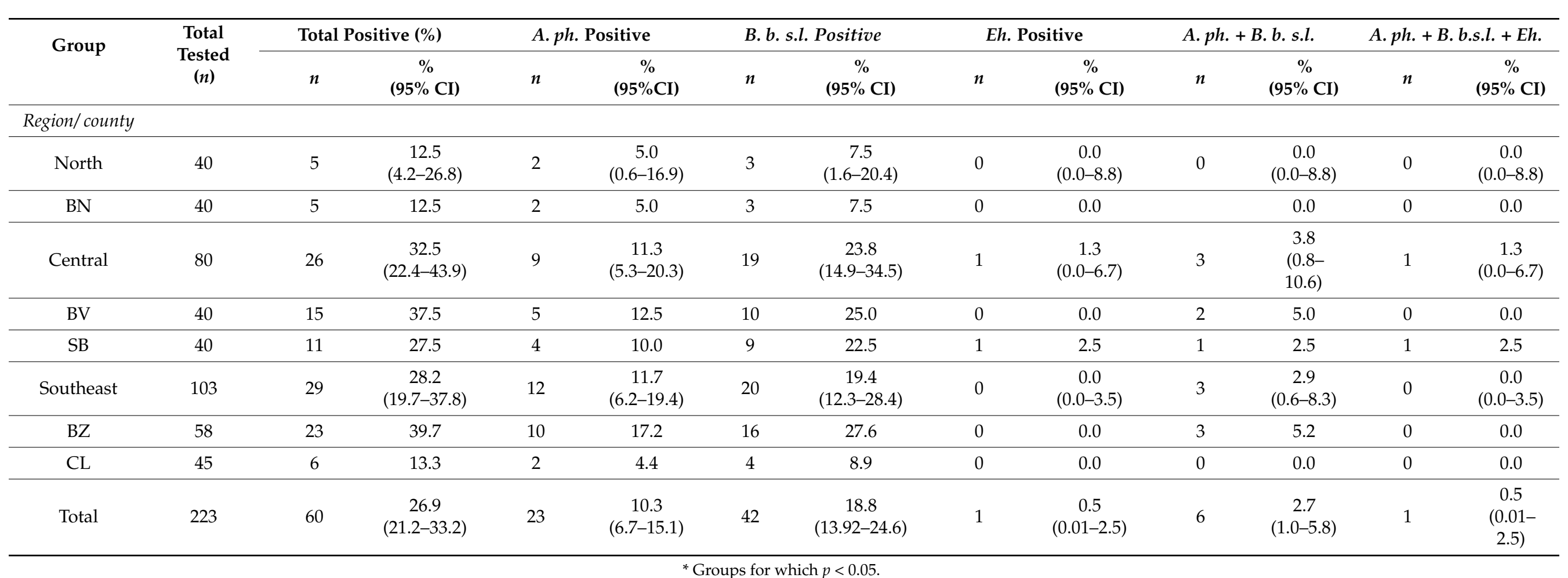


Horses were used for different activities. Horses from stud farms were used for breeding, races, and leisure, while working horses, which are raised in small, individual farms in rural areas of Romania, were used for various outdoor field activities, such as harvesting and transport of crops, working agricultural land, and forestry work.

All animals were apparently clinically healthy at the time of blood withdrawal and past or existing tick-borne diseases were not registered for any of them.

Altogether, $26.9 \%$ (95\% CI: 21.2-33.2\%) of the tested animals were positive for at least one of the tested pathogens.

Out of 223 horses, 23 (10.3\%; 95\% CI: 6.7-15.1\%) were seropositive for Ab against $A$. phagocytophilum, whereas 42 (18.8\%, 95\% CI: 13.92-24.6\%) and one (0.5\%, 95\% CI: 0.01-2.5\%) were seropositive for $\mathrm{Ab}$ against B. burgdorferi s.l., and Ehrlichia spp., respectively.

Positive animals for $A$. phagocytophilum and B. burgdorferi s.l. were identified in all three regions represented in this study. The mean frequency by region varied from $5.0 \%$ to $11.7 \%$ for $A$. phagocytophilum, while that for B. burgdorferi s.1. varied from $7.5 \%$ to $23.8 \%$. Higher seroprevalence values were registered in working horses than those from stud farms: $14.3 \%$ versus $6.8 \%$ for A. phagocytophilum; $28.6 \%$ versus $10.2 \%$ for B. burgdorferi s.1.

One male, mixed-breed working horse originating from central Romania was seroreactive for Ehrlichia spp. infection.

In $2.7 \%(6 / 223)$ and $0.5 \%(1 / 223)$ of samples, mixed infections with $A$. phagocytophilum plus B. burgdorferi s.l. and with A. phagocytophilum plus B. burgdorferi s.l. plus Ehrlichia spp., respectively, were detected.

Details on the prevalence of each pathogen by horse category and originating area are shown in Table 2.

\section{Discussion}

Studies on the presence and distribution of tick-borne pathogens in Romanian horses are very scarce. B. caballi and T. equi infections have been recently reported in asymptomatic horses in southeast Romania [24], while another recent study using molecular evidence also documented a clinical equine babesiosis outbreak caused by B. caballi in a tick-endemic area in Southern Romania [25]. Therefore, the present study provides serological evidence on the exposure of Romanian horses to three other tick-borne pathogens, namely, $A$. phagocytophilum, B. burgdorferi s.l., and Ehrlichia spp., for which little or no data are available.

The seroprevalence of $A$. phagocytophilum (10.3\%) in the present study is consistent with some serological surveys conducted in European countries, such as in northern Bulgaria $(12.0 \%)$ [26] and France (13.5\%) [21]. However, higher infection rates were reported in horses from Denmark (22.3\%) [20] or southern Bulgaria (20.0\%) [27]. All these studies used the same test technology. Other serological surveys used immunofluorescence assay (IFA) and ELISA for the detection of A. phagocytophilum in horses, such as in Italy $(9.0 \% ; 13.4 \%$; $7.4 \%$ ) [28-30], France (11.3\%) [31], Sweden (17.0\%) [32], Spain (6.5\%) [33], and Portugal $(3.0 \%)$ [34].

Similarly, quite wide ranges of prevalence values have also been reported from PCRbased surveys, from $0.33 \%$ to $25.62 \%[3,9,34]$.

Furthermore, our result showed higher seroprevalence values in working horses than horses raised in stud farms (14.3\% versus $6.8 \%$ ). This could be explained by the fact that working horses, being used in various outdoor field activities, are more exposed to ticks. There were no statistically significant differences in the seroprevalence according to the any horse category. However, older horses (>10 years) showed higher A. phagocytophilum seroprevalence $(13.0 \%)$ than younger horses, which could be explained by the fact that older horses are more likely to have been exposed to vector ticks.

To the best of our knowledge, this is the first serological survey on the occurrence of A. phagocytophilum in horses reared in Romania. However, A. phagocytophilum infection was reported in other domestic animal species in Romania, such as dogs, with a serological prevalence ranging from $2.25 \%$ to $16.0 \%$ [35,36]. The findings of the present study confirm the presence of this zoonotic tick-borne pathogen in horses in the investigated 
areas and suggest that horses can contribute to the natural cycle of this bacterium in Romania. Moreover, as all the seropositive horses were apparently clinically healthy, these findings support previous studies indicating that up to $50 \%$ of seropositive horses could respond immunologically to A. phagocytophilum exposure without developing clinical signs. Additionally, clinical anaplasmosis is very likely to be underdiagnosed given that most horses recover spontaneously and clinical signs are not specific, being rather similar to other infections [9]. Subsequently, clinicians should be informed about this fact, so that they can evaluate clinical disease, especially for horses newly introduced into an endemic area, which are more likely to develop illness [3,34].

In addition to $A$. phagocytophilum, two other tick-borne pathogens, B. burgdorferi s.l. and Ehrlichia spp., respectively, were serologically detected in horses in the investigated areas. Of those, A. phagocytophilum and B. burgdorferi s.l. are both transmitted by I. ricinus ticks.

In our study, $\mathrm{Ab}$ against $B$. burgdorferi s.l. were detected in horses originating from all three regions, with a mean frequency of $18.8 \%$, ranging from $7.5 \%$ to $23.8 \%$, by region. The findings show that most of the horses seroreactive for B. burgdorferi s.l. were found in central (23.8\%) and southeast (18.4\%) regions, thus suggesting a possibly higher tick density and a higher risk of becoming infested with an infected tick. This is also supported by a molecular study that reported higher infection rates $(22.0 \%$ and $19.0 \%)$ of questing I. ricinus ticks in central (Sibiu county) and southeast (Giurgiu county) Romania [19]. These reports provide evidence for the presence of a causative agent for Lyme disease in ticks from various regions of Romania, posing risks for human and animal infections in these areas.

In addition to this, a previous Romanian study, which to the best of our knowledge is the only study at this moment, on the seroprevalence of B. burgdorferi s.l. in horses showed a global seroprevalence of $11.92 \%$, but no correlations were found with age, gender, county, or occupation [37]. In our study, seroreactivity was correlated with raising system, gender, and breed, with male, mixed-breed, and working horses showing higher infection rates. This suggests that these horses, being often used outdoor for field duties, are more exposed to ticks and vectored pathogens. Additionally, local regional ecological factors may have an impact on the infection rate favoring the natural circulation of B. burgdorferi s.1. [13,14].

The B. burgdorferi s.1. seroprevalence of $18.8 \%$ in our study is consistent with other European surveys, such as in Bulgaria (15.5\%; 23.2\%) [26,27], Sweden (16.8\%) [38], and Germany (16.1\%) [39]. Higher infection rates were reported for horses in Denmark (29.0\%) [20], Poland (25.6\%) [40], and Slovakia (47.8\%) [41]. Furthermore, 4.5\%, 6.3-7.1\%, and 11.0\% of the examined horses in Sweden, Bulgaria, and Denmark, respectively, were seropositive for both B. burgdorferi s.l. and A. phagocytophilum $[20,26,27,38]$. The presence of dual infections is not surprising since both pathogens are vectored by I. ricinus ticks; however, coinfection with $A$. phagocytophilum and B. burgdorferi s.l. can increase disease severity, as recently reported [4]. In our study, $2.7 \%$ of the tested horses were co-exposed to A. phagocytophilum and B. burgdorferi, suggesting the possible association of $A$. phagocytophilum with B. burgdorferi s.l. in terms of endemic patterns and foci. Therefore, horses might be used as sentinels for early detection of emerging tick-borne diseases.

Several recent studies from North America (South Central United States, Oklahoma), South America (Brazil), and Central America (Nicaragua) documented reactivity to Ehrlichia spp. in horse serum [42,43], and molecular and phylogenetical studies suggest a potentially novel Ehrlichia species different from currently recognized species [22,44]. However, the main vector and the clinic significance of this newly identified equine Ehrlichia species are yet unknown.

In Europe, two recent serologic studies from Bulgaria, a neighboring country, also reported the seroreactivity to Ehrlichia spp. in horses (seroprevalence values of $0.5 \%$ and $3.9 \%$, respectively) [26,27]. In our study, one horse $(0.5 \%)$ was seroreactive to Ehrlichia spp., and it was also positive for A. phagocytophilum and B. burgdorferi s.l. A previous study in Romania confirmed the presence of E. canis DNA in ticks infesting dogs, in southeast Romania [45]. However, future extended surveys are planned to provide additional data 
for understanding if Romanian horses are reactive to E. canis or to a potential novel Ehrlichia species, as recently described [44].

Therefore, this preliminary work opens new avenues for further serological and molecular research to investigate the infection status of Ehrlichia spp. and other tick-borne pathogens in horse populations in Romania, for a better understanding of the epidemiology of equine tick-borne diseases.

Author Contributions: Conceptualization, A.M.B., M.I., and I.L.M.; methodology, A.M.B., M.I., and I.L.M.; investigation, A.M.B.; writing-original draft preparation, A.M.B.; writing-review and editing, M.I. and I.L.M. All authors have read and agreed to the published version of the manuscript.

Funding: This research was financially supported by the PhD doctoral grant of A.M.B., University of Agronomic Sciences and Veterinary Medicine of Bucharest, Romania.

Acknowledgments: The authors thank the horse owners and official veterinarians for their support.

Conflicts of Interest: The authors declare no conflict of interest.

Ethical Approval: Written permission was obtained from the management board of Romanian Agency Romsilva, D.C.E.A.C., for collection and subsequent analyses of the blood from horses (code: 10682/19/05/2016). Horse blood samples were collected by official veterinarians.

\section{References}

1. Parola, P.; Paddock, C.D.; Socolovschi, C.; Labruna, M.B.; Mediannikov, O.; Kernif, T.; Abdad, M.Y.; Stenos, J.; Bitam, I.; Fournier, P.E.; et al. Update on tick-borne rickettsioses around the world: A geographic approach. Clin. Microbiol. Rev. 2013, 26, 657-702. [CrossRef] [PubMed]

2. Edouard, S.; Koebel, C.; Goehringer, F.; Socolovschi, C.; Jaulhac, B.; Raoult, D.; Brouqui, P. Emergence of human granulocytic anaplasmosis in France. Ticks Tick Borne Dis. 2012, 3, 403-405. [CrossRef] [PubMed]

3. Stuen, S.; Granquist, E.; Silaghi, C. Anaplasma phagocytophilum-A widespread multi-host pathogen with highly adaptive strategies. Front. Cell. Infect. Microbiol. 2013, 3, 31. [CrossRef] [PubMed]

4. Baneth, G. Tick-borne infections of animals and humans: A common ground. Int. J. Parasitol. 2014, 44, 591-596. [CrossRef]

5. Rizzoli, A.; Hauffe, H.; Carpi, G.; Vourc, H.G.; Neteler, M.; Rosa, R. Lyme borreliosis in Europe. Eurosurveillance 2011, $16,19906$.

6. Dumler, J.S.; Barbet, A.F.; Bekker, C.P.J.; Dasch, G.A.; Palmer, G.H.; Ray, S.C.; Rikihisa, Y.; Rurangirwa, F.R. Reorganization of genera in the families Rickettsiaceae and Anaplasmataceae in the order Rickettsiales: Unification of some species of Ehrlichia with Anaplasma, Cowdria with Ehrlichia and Ehrlichia with Neorickettsia, description of six new species combinations and designation of Ehrlichia equi and "HGE agent" as subjective synonyms of Ehrlichia phagocytophila. Int. J. Syst. Evol. Microbiol. 2001, 51, $2145-2165$.

7. Jin, H.; Wei, F.; Liu, Q.; Qian, J. Epidemiology and control of human granulocytic anaplasmosis: A systematic review. Vector Borne Zoonotic Dis. 2012, 12, 269-274. [CrossRef]

8. Bermann, F.; Davoust, B.; Fournier, P.E.; Brisou-Lapointe, A.V.; Brouqui, P. Ehrlichia equi (Anaplasma phagocytophila) infection in an adult horse in France. Vet. Rec. 2002, 150, 787-788. [CrossRef]

9. Butler, C.M.; Nijhof, A.M.; Jongejan, F.; van der Kolk, J.H. Anaplasma phagocytophilum infection in horses in the Netherlands. Vet. Rec. 2008, 162, 216-217. [CrossRef]

10. Jahn, P.; Zeman, P.; Bezdekova, B.; Praskova, I. Equine granulocytic anaplasmosis in the Czech Republic. Vet. Rec. 2010, 166, 646-649. [CrossRef]

11. Gussmann, K.; Czech, C.; Hermann, M.; Schaarschmidt-Kiener, D.; von Loewenich, F.D. Anaplasma phagocytophilum infection in a horse from Switzerland with severe neurological symptoms. Schweiz. Arch. Für Tierheilkd. 2014, 156, 345-348. [CrossRef] [PubMed]

12. Jahfari, S.; Coipan, E.; Fonville, M.; van Leeuwen, A.; Hengeveld, P.; Heylen, D.; Heyman, P.; van Maanen, C.; Butler, C.; Földvári, G.; et al. Circulation of four Anaplasma phagocytophilum ecotypes in Europe. Parasites Vectors 2014, 7, 365. [CrossRef] [PubMed]

13. Butler, C.M.; Houwers, D.J.; Jongejan, F.; Van Der Kolk, J.H. Borrelia burgdorferi infections with special reference to horses. A review. Vet. Q. 2005, 27, 146-156. [CrossRef]

14. Divers, T.J.; Gardner, R.B.; Madigan, J.E.; Witonsky, S.G.; Bertone, J.J.; Swinebroad, E.L.; Schutzer, S.E.; Johnson, A.L. Borrelia burgdorferi infection and Lyme disease in North American horses: A consensus statement. J. Vet. Intern. Med. 2018, 32, 617-632. [CrossRef]

15. Ionita, M.; Mitrea, I.L.; Pfister, K.; Hamel, D.; Silaghi, C. Molecular evidence for bacterial and protozoan pathogens in hard ticks from Romania. Vet. Parasitol. 2013, 196, 71-76. [CrossRef]

16. Matei, I.A.; Kalmár, Z.; Magdaș, C.; Magdaș, V.; Toriay, H.; Dumitrache, M.O.; Ionică, A.M.; D’Amico, G.; Sándor, A.D.; Mărcuțan, D.I.; et al. Anaplasma phagocytophilum in questing Ixodes ricinus ticks from Romania. Ticks Tick Borne Dis. 2015, 6, 408-413. [CrossRef] 
17. Dumitrache, M.O.; Matei, I.A.; Ionică, A.M.; Kalmár, Z.; D’Amico, G.; Sikó-Barabási, S.; Ionescu, D.T.; Gherman, C.M.; Mihalca, A.D. Molecular detection of Anaplasma phagocytophilum and Borrelia burgdorferi sensu lato genospecies in red foxes (Vulpes vulpes) from Romania. Parasites Vectors 2015, 8, 514. [CrossRef]

18. Matei, I.A.; D’Amico, G.; Ionică, A.M.; Kalmár, Z.; Corduneanu, A.; Sándor, A.D.; Fit, N.; Bogdan, L.; Gherman, C.M.; Mihalca, A.D. New records for Anaplasma phagocytophilum infection in small mammal species. Parasites Vectors 2018, 11, 193. [CrossRef]

19. Coipan, E.C.; Vladimirescu, A.F. Ixodes ricinus ticks (Acari: Ixodidae): Vectors for Lyme disease spirochetes in Romania. Exp. Appl. Acarol. 2011, 54, 293-300. [CrossRef]

20. Hansen, M.G.B.; Christoffersen, M.; Thuesen, L.R.; Petersen, M.R.; Bojesen, A.M. Seroprevalence of Borrelia burgdorferi sensu lato and Anaplasma phagocytophilum in Danish horses. Acta Vet. Scand. 2010, 52, 3. [CrossRef]

21. Maurizi, L.; Marie, J.-L.; Courtin, C.; Gorsane, S.; Chal, D.; Davoust, B. Seroprevalence survey of equine anaplasmosis in France and in sub-Saharan Africa. Clin. Microbiol. Infect. 2009, 15, 68-69. [CrossRef] [PubMed]

22. O'Nion, V.L.; Montilla, H.J.; Qurollo, B.A.; Maggi, R.G.; Hegarty, B.C.; Tornquist, S.J.; Breitschwerdt, E.B. Potentially novel Ehrlichia species in horses, Nicaragua. Emerg. Infect. Dis. 2015, 21, 335-338. [CrossRef] [PubMed]

23. Chandrashekar, R.; Daniluk, D.; Moffitt, S.; Lorentzen, L.; Williams, J. Serologic diagnosis of equine borreliosis: Evaluation of an in-clinic enzyme-linked immunosorbent assay $\left(\mathrm{SNAP}^{\circledR} 4 \mathrm{Dx}^{\circledR}\right)$. Intern. J. Appl. Res. Vet. Med. 2008, 6, 145-150.

24. Gallusová, M.; Qablan, M.A.; D’Amico, G.; Oborník, M.; Petrželková, K.J.; Mihalca, A.D.; Modrý, D. Piroplasms in feral and domestic equines in rural areas of the Danube Delta, Romania, with survey of dogs as a possible reservoir. Vet. Parasitol. 2014, 206, 287-292. [CrossRef]

25. Ionita, M.; Nicorescu, I.M.; Pfister, K.; Mitrea, I.L. Parasitological and molecular diagnostic of a clinical Babesia caballi outbreak in Southern Romania. Parasitol. Res. 2018, 117, 2333-2339. [CrossRef]

26. Tsachev, I.; Baymakova, M.; Pantchev, N. Seroprevalence of Anaplasma phagocytophilum, Ehrlichia spp. and Borrelia burgdorferi infections in horses: First report from Northern Bulgaria-Short communication. Acta Vet Hung. 2019, 67, 197-203. [CrossRef]

27. Tsachev, I.; Pantchev, N.; Marutsov, P.; Petrov, V.; Gundasheva, D.; Baymakova, M. Serological Evidence of Borrelia burgdorferi, Anaplasma phagocytophilum and Ehrlichia spp. infections in horses from Southeastern Bulgaria. Vector Borne Zoonotic Dis. 2018, 18, 588-594. [CrossRef]

28. Giudice, E.; Giannetto, C.; Furco, V.; Alongi, A.; Torina, A. Anaplasma phagocytophilum seroprevalence in equids: A survey in Sicily (Italy). Parasitol. Res. 2012, 111, 951-955. [CrossRef]

29. Laus, F.; Veronesi, F.; Passamonti, F.; Paggi, E.; Cerquetella, M.; Hyatt, D.; Tesei, B.; Fioretti, D.P. Prevalence of tick borne pathogens in horses from Italy. J. Vet. Med. Sci. 2013, 75, 715-720. [CrossRef] [PubMed]

30. Veronesi, F.; Morganti, G.; Ravagnan, S.; Laus, F.; Spaterna, A.; Diaferia, M.; Moretti, A.; Fioretti, D.P.; Capelli, G. Molecular and serological detection of tick-borne pathogens in donkeys (Equus asinus) in Italy. Vet. Microbiol. 2014, 173, 348-354. [CrossRef] [PubMed]

31. Leblond, A.; Pradier, S.; Pitel, P.H.; Fortier, G.; Boireau, P.; Chadoeuf, J.; Sabatier, P. Enquête épidémiologique sur l'anaplasmose équine. [An epidemiological survey of equine anaplasmosis (Anaplasma phagocytophilum) in southern France]. Rev. Sci. Tech. 2005, 24, 899-908. [CrossRef]

32. Engvall, E.O.; Egenvall, A. Granulocytic ehrlichiosis in Swedish dogs and horses. Int. J. Med. Microbiol. 2002, 291, 100-103. [CrossRef]

33. Amusategui, I.; Sainz, A.; Tesouro, M.A. Serological evaluation of Anaplasma phagocytophilum infection in livestock in northwestern Spain. Ann. N. Y. Acad. Sci. 2006, 1078, 487-490. [CrossRef] [PubMed]

34. Santos, A.S.; Bacellar, F.; Dumler, J.S. A 4-year study of Anaplasma phagocytophilum in Portugal. Clin. Microbiol. Infect. 2008, 15, 46-47. [CrossRef] [PubMed]

35. Anghel, R.G.; Mitrea, I.L.; Ionita, M. Retrospective study on prevalence of canine vector borne diseases in Bucharest area. Rev. Rom. Med. Vet. 2016, 26, 27-32.

36. Ionita, M.; Enachescu, V.; Mitrea, I. Preliminary data on serological survey of exposure to arthropod-borne pathogens in stray dogs from Bucharest, Romania. Sci. Work. Ser. C. Vet. Med. 2012, 58, 220-225.

37. Kiss, T.; Cadar, D.; Krupaci, A.F.; Bordeanu, A.; Brudaşcă, G.F.; Mihalca, A.D.; Mircean, V.; Gliga, L.; Dumitrache, M.O.; Spînu, M.V. Serological reactivity to Borrelia burgdorferi sensu lato in dogs and horses from distinct areas in Romania. Vector Borne Zoonotic Dis. 2011, 11, 1259-1262. [CrossRef] [PubMed]

38. Egenvall, A.; Franzén, P.; Gunnarsson, A.; Engvall, E.O.; Vågsholm, I.; Wikström, B.; Artursson, K. Cross-sectional study of the seroprevalence to Borrelia burgdorferi sensu lato and granulocytic Ehrlichia spp. and demographic, clinical and tick-exposure factors in Swedish horses. Prev. Vet. Med. 2001, 49, 191-208. [CrossRef]

39. Käsbohrer, A.; Schönberg, A. Serologic studies of the occurrence of Borrelia burgdorferi in domestic animals in Berlin (West). Berl. Münch. Tierärztl. Wochenschr. 1990, 103, 374-378. [PubMed]

40. Stefanciková, A.; Adaszek, L.; Petko, B.; Winiarczyk, S.; Dudinák, V. Serological evidence of Borrelia burgdorferi sensu lato in horses and cattle from Poland and diagnostic problems of Lyme borreliosis. Ann. Agric. Environ. Med. 2008, 15, 37-43. [PubMed]

41. Stefancíková, A.; Derdáková, M.; Škardová, I.; Szestáková, E.; Cisláková, L.; Kovácová, D.; Stanko, M.; Petko, B. Prevalence of antibodies to Borrelia burgdorferi in horses of east Slovakia. Vet. Med. Czech. 2000, 45, 227-231. 
42. Carmichael, R.C.; Duell, J.R.; Holbrook, T.C.; Herrin, B.H.; Leutenegger, C.M.; O'Connor, T.P.; Little, S.E. Antibodies reactive to Ehrlichia spp. are common in Oklahoma horses. Vector Borne Zoonotic Dis. 2014, 14, 552-556. [CrossRef]

43. Vieira, R.; Vieira, T.; Nascimento, D.; Martins, T.; Krawczak, F.; Labruna, M.; Chandrashekar, R.; Marcondes, M.; Biondo, A.; Vidotto, O. Serological survey of Ehrlichia species in dogs, horses and humans: Zoonotic scenery in a rural settlement from Southern Brazil. Rev. Inst. Med. Trop Sao Paulo 2013, 55, 335-340. [CrossRef] [PubMed]

44. Vieira, T.; Qurollo, B.; Mongruel, A.; Baggio, R.; Vidotto, O.; Breitschwerdt, E.; Vieira, R. Potentially same novel Ehrlichia species in horses in Nicaragua and Brazil. Emerg. Infect. Dis. 2018, 24, 953. [CrossRef]

45. Ionita, M.; Silaghi, C.; Mitrea, I.L.; Edouard, S.; Parola, P.; Pfister, K. Molecular detection of Rickettsia conorii and other zoonotic spotted fever group rickettsiae in ticks, Romania. Ticks Tick Borne Dis. 2016, 7, 150-153. [CrossRef] [PubMed] 